\title{
Bioactivity of Oils from Medicinal Plants against Immature Stages of Dengue Mosquito Aedes aegypti (Diptera: Culicidae)
}

\author{
Shabab Nasir ${ }^{1 *}$, Marriam Batool ${ }^{1}$, Syed Makhdoom Hussain ${ }^{1}$, Iram Nasir ${ }^{2}$, Faisal Hafeez ${ }^{3}$ and Mustapha Debboun ${ }^{4}$ \\ ${ }^{1}$ Department of Zoology, Wildlife \& Fisheries, Government College University, Faisalabad, Pakistan \\ ${ }^{2}$ Department of Statistics, Government College University, Faisalabad, Pakistan \\ ${ }^{3}$ Institute of Entomological Research, Ayub Agriculture Research Institute, Faisalabad, Pakistan \\ ${ }^{4}$ Academy of Health Sciences, Department of Preventive Health Servicers, Fort Sam Houston, Texas \\ *For correspondence: flourenceshabab@yahoo.com
}

\begin{abstract}
To evaluate the efficacy of the essential oils extracted from the branches and leaves of eucalyptus (Eucalyptus globules Labill.), neem (Azadirachta indica A. Juss), peppermint (Mentha piperita L.), basil (Ocimum basilicum L.) and from rhizome of ginger (Zingiber officinale Rosc.) against the larvae and pupae of Aedes aegypti L. The essential oils were extracted with Soxhlet apparatus using petroleum ether as a solvent. The oils were evaluated against $1^{\text {st }}, 2^{\text {nd }}, 3^{\text {rd }}, 4^{\text {th }}$ instar larvae and the pupae of Ae. aegypti following WHO protocol. The dead individuals in all stages were counted after 8, 16, 24 and 48 hours in treatments of different concentrations (100, 200, 300 and 400 ppm). The percent mortality in each stage was determined and consequently $\mathrm{LC}_{50} \mathrm{~s}$ were also calculated by Probit analysis. A control treatment was also run by using petroleum ether in which mortality $(<6 \%)$ of different life stages of Aedes mosquitoes was observed. Results showed that higher mortality was observed in early life stages than later ones. Ginger was more effective having lowest $\mathrm{LC}_{50}$ after $8 \mathrm{~h}(142 \mathrm{ppm})$ and $16 \mathrm{~h}(8.5$ ppm) against $1^{\text {st }}$ instar larvae followed by peppermint, basil, eucalyptus and neem. However, eucalyptus and peppermint were efficacious after $24 \mathrm{~h}(66$ and $84 \mathrm{ppm})$ and $48 \mathrm{~h}$ (19.5 and $17 \mathrm{ppm})$, respectively. Ginger oil showed high efficacy in short period of the time $(8$ and $16 \mathrm{~h}$ ) followed by peppermint, basil, eucalyptus and neem, whereas eucalyptus oil exhibited its lethality after $24 \mathrm{~h}$, whilst peppermint has longer potency and persistence $(48 \mathrm{~h})$ than other plant oils. For pupal stage, peppermint had knockdown effect $(8 \mathrm{~h})$ followed by eucalyptus $(16 \mathrm{~h})$, basil $(24 \mathrm{~h})$ and neem $(48 \mathrm{~h})$. From these results, it can be concluded that the oils of E. globules and M. piperita were effective larvicide against the immature stages of Ae. aegypti. (C) 2015 Friends Science Publishers
\end{abstract}

Keywords: Larvae; Medicinal plants, Oils, Pupae; Aedes aegypti; Mortality

\section{Introduction}

Aedes aegypti L., a vector of dengue fever, has assumed an alarming position of preponderance in Pakistan. The number of death due to this fever is increasing every year. The Government of Punjab (Pakistan) has established emergence cell to combat this vector (Anonymous, 2013). In Punjab, Pakistan, there were 21,292 confirmed dengue cases with 352 deaths during 2011 (Anonymous, 2013). To date neither a vaccine nor a treatment for dengue virus is available; the only way to ward off this disease is to control the vector, Ae. aegypti. The immature stages of this mosquito can efficiently be controlled by source reduction and chemical application. Source reduction method has its limitations due to growth of residential areas and poor sanitation facilities. The overuse of synthetic insecticides may foster development of resistance, which alone is sufficient to cause control failure (Sarwar et al., 2009; Naz et al., 2014). Thus, new strategies for the control of immature stages of mosquito should be sorted out (Junwei et al., 2006). In this respect, plant extracts may be used as an alternative of the chemical insecticides, because they constitute a rich source of bioactive compounds that are easily biodegradable and limit case of resistance in mosquitoes (Gbolade et al., 2000; Bokhari et al., 2014). Many biologists have studied the effectiveness of plant oils such as Azadirachta indica A. Juss., Lantana Camara L., Litsea elliptica B., Momordica charantia L., Syringodium isoetifolium Asch., Vitex agnus L. and plants from Citrus family against the mosquitoes and found them effective against larvae and adults. These oils can be categorised as larvicide or repellent to adult stages (Chantraine et al., 1998; Ansari et al., 2000; Yang et al., 2002; Amer and Mehlhorn, 2006; Senthil-Nathan et al., 2006; Tiwary et al., 2007; Anees, 2008; Bakkali et al., 2008; Akram et al., 2010; Hafeez et al., 2011; Sadr ud Din et al., 2011). 
The larvicide and repellent activities of plant oils have been documented against many mosquito vector species. The main focus of the earlier researchers was on lethal concentration, lethal time and percent mortality against a single larval instar but a little work was done on total life span including pupa. The present work has been planned to find out the effects of essential oils from the branches and leaves of eucalyptus (Eucalyptus globules), neem (Azadirachta indica), peppermint (Mentha piperita), basil (Ocimum basilicum) and rhizome of ginger (Zingiber officinale) on all larval instars and pupae of Ae. aegypti.

\section{Materials and Methods}

\section{Collection and Rearing of Mosquitoes}

Larvae, pupae and adult mosquitoes were collected from residential areas (Faisalabad, Punjab). Larvae and pupae were collected with the help of a standard dipper, kept and stored in a plastic bottle tied up with muslin cloth replacing lid for aeration. Then the collected material was carried to the Department of Zoology, Wildlife and Fisheries, Government College University, Faisalabad for sorting and rearing. The larvae and pupae were separated. The larvae were kept in rearing trays and pupae were kept in beakers inside the cages. After emergence, the females were fed on blood of white rat for egg laying. The collected eggs were shifted in the plastic trays with fresh water for hatching inside laboratory running at $26 \pm 11^{\circ} \mathrm{C}$ and $75 \pm 5 \% \mathrm{RH}$. The larvae were fed on fish diet and $1^{\text {st }}, 2^{\text {nd }}, 3^{\text {rd }}, 4^{\text {th }}$ instar larvae and pupae were used for the bioassay (Kumar et al., 2011).

\section{Collection and Preparation of Plant Material for Oil Extraction}

Different plant materials selected for the oil extraction are presented in Table 1. These plant materials were collected from Government College University, Faisalabad ( $31^{\circ} 30^{\prime} \mathrm{N}$, $73^{\circ} 05^{\prime}$ E). The plant materials were washed with tap water to remove dust particles and were dried at room temperature. After that these materials were also dried for 48 hours at $60^{\circ} \mathrm{C}$ in an electric oven. The dried material was grinded with the help of an electrical grinder and the resultant powder was stored in the plastic bottles after sieving for oil extraction.

\section{Extraction of Oil}

Essential oils were extracted from the selected plant materials with the help of Soxhlet apparatus (Cheng et al., 2009). Twenty five grams powder of each plant material with $250 \mathrm{~mL}$ of solvent (petroleum ether) was used for 8 to $24 \mathrm{~h}$ to extract oil through Soxhlet apparatus. After extraction, vacuum evaporator was used to evaporate solvent to attain filtrate in dehydrated form, which was then stored in airtight jar.
Table 1: List of plants and their parts used for oil extraction

\begin{tabular}{llll}
\hline $\begin{array}{l}\text { English } \\
\text { names }\end{array}$ & Binomial names & Families & Parts \\
\hline Eucalyptus & Eucalyptus globules & Myrtaceae & Branches and leaves \\
Neem & Azadirachta indica & Meliaceae & Branches and leaves \\
Mint & Mentha piperita & Lamiaceae & Branches and leaves \\
Basil & Ocimum basilicum & Lamiaceae & Branches and leaves \\
Ginger & Zingiber officinale & Zingiberaceae & Rhizome \\
\hline
\end{tabular}

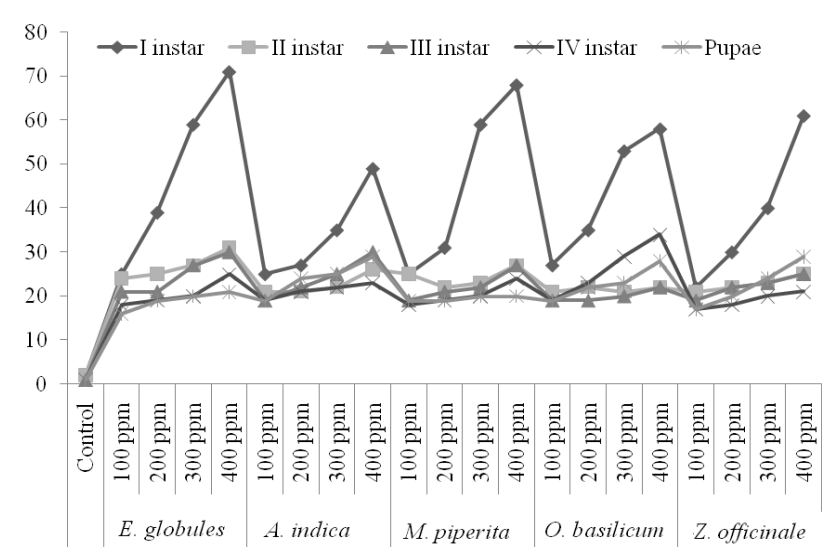

Fig. 1: Mortality (\%) of various life stages of Ae. aegypti mosquitoes after 8 hours in the concentrations of different plant oils

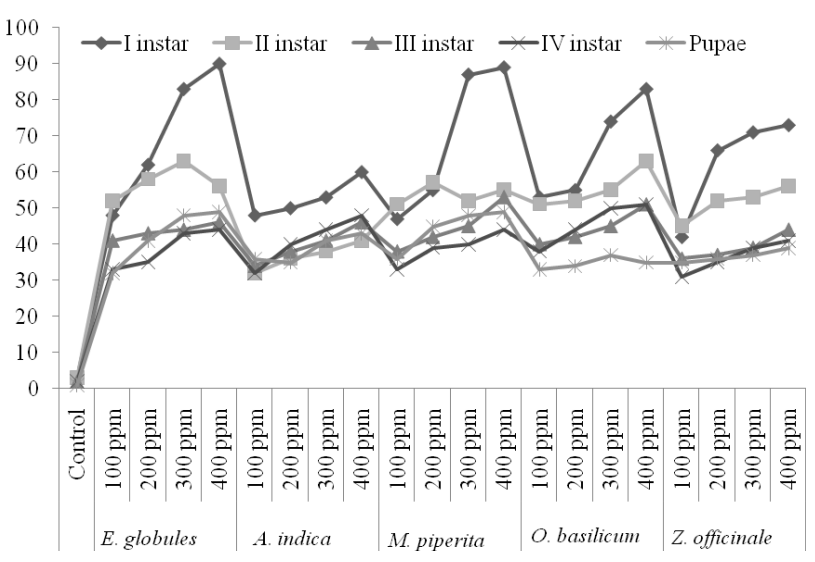

Fig. 2: Mortality (\%) of various life stages of Ae. aegypti mosquitoes after 16 hours in the concentrations of different plant oils

\section{Preparation of Solution}

From extracted oils, 100, 200, 300 and 400 ppm concentrations were prepared by dissolving the $0.5,1.0,1.5$ and $2.0 \mu \mathrm{L}$ of extracted oil in $1 \mathrm{~mL}$ of petroleum ether, respectively and required volume was made with distilled water.

\section{Larvicide Bioassays}

Larvicide bioassays were accomplished under laboratory 
Efficacy of Plant Extracts against Dengue Mosquito / Int. J. Agric. Biol., Vol. 17, No. 4, 2015

Table 2: Toxicity of plant extracts against larval instars and pupae of Ae. aegypti

\begin{tabular}{|c|c|c|c|c|c|c|c|c|c|}
\hline \multirow[t]{2}{*}{ Plant extract } & \multirow[t]{2}{*}{ Life stages } & \multicolumn{4}{|c|}{ After interval of $8 \mathrm{~h}$} & \multicolumn{4}{|c|}{ After interval of $16 \mathrm{~h}$} \\
\hline & & $\mathrm{LC}_{50}$ & Slope \pm S.E & $\chi^{2}$ & P value & $\mathrm{LC}_{50}$ & Slope \pm S.E & $\chi^{2}$ & $P$ value \\
\hline \multirow{5}{*}{$\begin{array}{l}\text { Eucalyptus (Eucalyptus } \\
\text { globules) }\end{array}$} & $1^{\text {st }}$ instar & 581 & $1.62 \pm 0.33$ & 2.85 & 0.24 & 189 & $1.95 \pm 0.19$ & 4.92 & 0.00 \\
\hline & $2^{\text {nd }}$ instar & 571 & $0.55 \pm 0.31$ & 0.46 & 0.79 & 340 & $0.46 \pm 0.15$ & 0.04 & 0.97 \\
\hline & $3^{\text {rd }}$ instar & 591 & $1.01 \pm 0.37$ & 0.90 & 0.63 & 496 & $0.25 \pm 0.21$ & 0.00 & 0.99 \\
\hline & $4^{\text {th }}$ instar & 172 & $1.31 \pm 0.54$ & 0.76 & 0.68 & 810 & $0.81 \pm 0.23$ & 1.52 & 0.46 \\
\hline & Pupae & 467 & $0.94 \pm 0.5$ & 0.16 & 0.92 & 519 & $0.92 \pm 0.21$ & 0.00 & 1 \\
\hline \multirow{5}{*}{$\begin{array}{l}\text { Neem (Azadirach- } \\
\text { ta indica) }\end{array}$} & $1^{\text {st }}$ instar & 652 & $6.66 \pm 0.19$ & 1.20 & 0.54 & 566 & $1.65 \pm 0.33$ & 3.28 & 0.19 \\
\hline & $2^{\text {nd }}$ instar & 76 & $0.98 \pm 0.13$ & 0.50 & 0.97 & 357 & $0.93 \pm 0.49$ & 0.90 & 0.63 \\
\hline & $3^{\text {rd }}$ instar & 372 & $0.84 \pm 0.18$ & 1.74 & 0.41 & 152 & $1.22 \pm 0.47$ & 0.81 & 0.66 \\
\hline & $4^{\text {th }}$ instar & 500 & $0.32 \pm 0.17$ & 0.57 & 0.75 & 471 & $0.40 \pm 0.19$ & 0.31 & 0.85 \\
\hline & Pupae & 218 & $0.45 \pm 0.21$ & 0.47 & 0.79 & 780 & $0.58 \pm 0.19$ & 0.04 & 0.98 \\
\hline \multirow{5}{*}{$\begin{array}{l}\text { Peppermint (Mentha } \\
\text { piperita) }\end{array}$} & $1^{\text {st }}$ instar & 274 & $3.40 \pm 3.10$ & 15.2 & 0.00 & 184 & $2.63 \pm 0.25$ & 39.3 & 0.00 \\
\hline & $2^{\text {nd }}$ instar & 463 & $0.7 \pm 0.38$ & 0.32 & 0.85 & 395 & $0.43 \pm 0.16$ & 0.07 & 0.96 \\
\hline & $3^{\text {rd }}$ instar & 226 & $1.05 \pm 0.46$ & 0.82 & 0.66 & 972 & $0.64 \pm 0.22$ & 0.88 & 0.64 \\
\hline & $4^{\text {th }}$ instar & 262 & $1.1 \pm 0.54$ & 0.29 & 0.86 & 285 & $0.75 \pm 0.21$ & 0.15 & 0.92 \\
\hline & Pupae & 190 & $1.00 \pm 0.40$ & 0.23 & 0.88 & 660 & $0.67 \pm 1.19$ & 0.04 & 0.97 \\
\hline Basil & 1st instar & 323 & $0.29 \pm 0.17$ & 0.67 & 0.71 & 396 & $1.52 \pm 0.23$ & 1.30 & 0.52 \\
\hline \multirow[t]{4}{*}{ (Ocimum basilicum) } & $2^{\text {nd }}$ instar & 53 & $0.83 \pm 0.13$ & 1.47 & 0.47 & 441 & $0.76 \pm 0.48$ & 0.19 & 0.93 \\
\hline & $3^{\text {rd }}$ instar & 198 & $0.46 \pm 0.14$ & 0.53 & 0.76 & 334 & $1.08 \pm 0.58$ & 0.57 & 0.74 \\
\hline & $4^{\text {th }}$ instar & 326 & $0.38 \pm 0.15$ & 0.06 & 0.96 & 887 & $1.33 \pm 0.36$ & 0.23 & 0.88 \\
\hline & Pupae & 946 & $0.41 \pm 0.18$ & 0.39 & 0.85 & 226 & $0.86 \pm 0.36$ & 0.83 & 0.66 \\
\hline \multirow{5}{*}{$\begin{array}{l}\text { Ginger (Zingiber } \\
\text { officinale) }\end{array}$} & $1^{\text {st }}$ instar & 142 & $1.30 \pm 1.20$ & 31.4 & 0.00 & 8.5 & $1.31 \pm 0.16$ & 1.06 & 0.58 \\
\hline & $2^{\text {nd }}$ instar & 181 & $0.98 \pm 0.13$ & 0.50 & 0.96 & 74. & $0.93 \pm 0.49$ & 0.90 & 0.64 \\
\hline & $3^{\text {rd }}$ instar & 395 & $0.84 \pm 0.18$ & 1.70 & 0.41 & 372 & $1.20 \pm 0.45$ & 0.81 & 0.66 \\
\hline & $4^{\text {th }}$ instar & 589 & $0.33 \pm 0.17$ & 0.57 & 0.75 & 400 & $0.43 \pm 0.18$ & 0.31 & 0.85 \\
\hline & Pupae & 815 & $0.45 \pm 0.21$ & 0.47 & 0.79 & 578 & $0.57 \pm 0.19$ & 0.04 & 0.97 \\
\hline
\end{tabular}

Table 3: Toxicity of plant extracts against larvae and pupae of Ae. aegypti

\begin{tabular}{|c|c|c|c|c|c|c|c|c|c|}
\hline \multirow[t]{2}{*}{ Plants } & \multirow[t]{2}{*}{ Life stages } & \multicolumn{4}{|c|}{ After interval of $24 \mathrm{~h}$} & \multicolumn{4}{|c|}{ After interval of $48 \mathrm{~h}$} \\
\hline & & $\mathrm{LC}_{50}$ & Slope \pm S.E & $\chi^{2}$ & $\mathrm{P}$ value & $\mathrm{LC}_{50}$ & Slope \pm S.E & $\chi^{2}$ & $\mathrm{P}$ value \\
\hline$\overline{\text { Eucalyptus (Eucalyptus }}$ & $1^{\text {st }}$ instar & 66 & $1.09 \pm 0.15$ & 6.38 & 0.04 & 19.5 & $0.67 \pm 0.17$ & 7.67 & 0.02 \\
\hline \multirow[t]{4}{*}{ globules) } & $2^{\text {nd }}$ instar & 99 & $0.74 \pm 0.13$ & 0.99 & 0.60 & 86 & $0.69 \pm 0.13$ & 1.24 & 0.53 \\
\hline & $3^{\text {rd }}$ instar & 161 & $0.30 \pm 0.14$ & 0.78 & 0.67 & 145 & $0.36 \pm 0.14$ & 3.57 & 0.16 \\
\hline & $4^{\text {th }}$ instar & 301 & $0.17 \pm 0.17$ & 0.04 & 0.98 & 362 & $0.60 \pm 0.16$ & 1.85 & 0.39 \\
\hline & Pupae & 799 & $0.52 \pm 0.19$ & 0.79 & 0.67 & 757 & $0.51 \pm 0.19$ & 0.37 & 0.83 \\
\hline \multirow{5}{*}{$\begin{array}{l}\text { Neem (Azadirachta } \\
\text { indica) }\end{array}$} & $1^{\text {st }}$ instar & 421 & $0.74 \pm 0.18$ & 9.77 & 0.00 & 181 & $1.05 \pm 0.15$ & 4.70 & 0.09 \\
\hline & $2^{\text {nd }}$ instar & 115 & $0.82 \pm 0.26$ & 0.16 & 0.92 & 395 & $121 \pm 0.12$ & 0.67 & 0.13 \\
\hline & $3^{\text {rd }}$ instar & 117 & $0.80 \pm 0.26$ & 0.22 & 0.89 & 597 & $0.23 \pm 0.17$ & 0.20 & 0.90 \\
\hline & $4^{\text {th }}$ instar & 524 & $0.35 \pm 0.18$ & 1.14 & 0.56 & 517 & $0.88 \pm 0.34$ & 0.17 & 0.91 \\
\hline & Pupae & 709 & $0.51 \pm 0.18$ & 1.47 & 0.79 & 229 & $1.80 \pm 0.51$ & 7.92 & 0.19 \\
\hline \multirow{5}{*}{$\begin{array}{l}\text { Peppermint (Mentha } \\
\text { piperita) }\end{array}$} & $1^{\text {st }}$ instar & 84 & $1.2 \pm 0.17$ & 8.4 & 0.01 & 17 & $0.56 \pm 0.14$ & 7.47 & 0.02 \\
\hline & $2^{\text {nd }}$ instar & 135 & $0.50 \pm 0.14$ & 4.86 & 0.00 & 212 & $0.22 \pm 0.12$ & 0.68 & 0.71 \\
\hline & $3^{\text {rd }}$ instar & 346 & $0.74 \pm 0.16$ & 1.95 & 0.37 & 342 & $0.24 \pm 0.14$ & 0.15 & 0.93 \\
\hline & $4^{\text {th }}$ instar & 549 & $0.36 \pm 0.19$ & 0.80 & 0.67 & 723 & $0.51 \pm 0.18$ & 0.82 & 0.66 \\
\hline & Pupae & 715 & $0.53 \pm 0.18$ & 0.16 & 0.92 & 323 & $0.29 \pm 0.17$ & 0.67 & 0.75 \\
\hline \multirow{5}{*}{$\begin{array}{l}\text { Basil (Ocimum } \\
\text { basilicum) }\end{array}$} & 1st instar & 206 & $1.37 \pm 1.07$ & 17.0 & 0.00 & 120 & $0.99 \pm 0.13$ & 0.46 & 0.79 \\
\hline & $2^{\text {nd }}$ instar & 595 & $0.41 \pm 1.69$ & 2.37 & 0.30 & 313 & $0.51 \pm 0.15$ & 2.19 & 0.33 \\
\hline & $3^{\text {rd }}$ instar & 659 & $0.45 \pm 0.20$ & 0.98 & 0.60 & 523 & $0.33 \pm 0.15$ & 0.33 & 0.84 \\
\hline & $4^{\text {th }}$ instar & 589 & $0.81 \pm 0.20$ & 0.23 & 0.89 & 568 & $0.39 \pm 0.18$ & 0.52 & 0.67 \\
\hline & Pupae & 219 & $0.58 \pm 0.25$ & 0.60 & 0.97 & 946 & $0.44 \pm 0.22$ & 0.40 & 0.81 \\
\hline \multirow{5}{*}{$\begin{array}{l}\text { Ginger (Zingiber } \\
\text { officinale) }\end{array}$} & $1^{\text {st }}$ instar & 466 & $0.64 \pm 0.08$ & 8.77 & 0.00 & 417 & $1.04 \pm 0.12$ & 3.70 & 0.08 \\
\hline & $2^{\text {nd }}$ instar & 576 & $0.82 \pm 0.26$ & 0.16 & 0.98 & 955 & $124 \pm 0.12$ & 0.67 & 0.14 \\
\hline & $3^{\text {rd }}$ instar & 152 & $0.80 \pm 0.26$ & 0.22 & 0.89 & 998 & $0.23 \pm 0.17$ & 0.20 & 0.90 \\
\hline & $4^{\text {th }}$ instar & 464 & $0.35 \pm 0.17$ & 1.14 & 0.56 & 422 & $0.88 \pm 0.33$ & 0.17 & 0.91 \\
\hline & Pupae & 777 & $0.52 \pm 0.18$ & 1.47 & 0.79 & 704 & $1.80 \pm 0.51$ & 7.92 & 0.18 \\
\hline
\end{tabular}

conditions in accordance with WHO technique for mosquito with the transparency adjustment (WHO, 2009). In each glass beaker twenty five $1^{\text {st }}, 2^{\text {nd }}, 3^{\text {rd }}$ and $4^{\text {th }}$ instar larvae were introduced separately containing various oil solution concentrations from $100 \mathrm{ppm}$ to $400 \mathrm{ppm}$ (Mohtar et al., 1999). Control treatments had said volume of water instead of oil in petroleum ether. The treatments were repeated thrice under laboratory conditions at $27 \pm 2^{\circ} \mathrm{C}$ and $65 \pm 5 \%$ $\mathrm{RH}$ using CRD. As soon as possible the dead larvae were removed from the beaker to prevent the rapid death of further larvae, after 8, 16, 24 and $48 \mathrm{~h}$. From the average of three replicates, percentage mortality was counted by using the following formula (Sumroiphon et al., 2006).

Percentage mortality $=($ Number of dead larvae/Number of larvae tested $) \times 100$ 


\section{Statistical Analysis}

Abbot's formula was applied to calculate the corrected mortality and then the data were analyzed by Probit analysis (Abbott, 1925; Finney, 1971), using Minitab-15 statistical software for determining $\mathrm{LC}_{50}$ and related parameters.

\section{Results}

The percent mortality of different life stages of Ae. aegypti in different concentrations of plant oils at different posttreatment time intervals are shown in Figs. 1-4. Highest mortality was seen in case of $1^{\text {st }}$ instar larvae than all other immature life stages with all oils and their concentrations. After $8 \mathrm{~h}$, about $70 \%$ mortality of the $1^{\text {st }}$ instar larvae was seen in case of Eucalyptus and peppermint with 400 ppm and least mortality was seen in case of neem oil (50\%). In case of all other immature life stages, the mortality percentage was almost same with all oils, i.e., close to $25 \%$. The control treatment of this time point had shown $2 \%$ mortality (Fig. 1). After $16 \mathrm{~h}$, about $90 \%$ mortality of the $1^{\text {st }}$ instar larvae was seen in case of Eucalyptus and peppermint with $400 \mathrm{ppm}$, while basil showed about $83 \%$ mortality with $400 \mathrm{ppm}$ and least mortality ( 60\%) was seen in case of neem oil (Fig. 2). After $24 \mathrm{~h}$, more than $90 \%$ mortality of the $1^{\text {st }}$ instar larvae was observed in all oils except Eucalyptus and mint; although with higher concentration more than $60 \%$ mortality was observed in all other life stages, while control had only $4 \%$ mortality (Fig. 3). After $48 \mathrm{~h}, 100 \%$ mortality $\left(1^{\text {st }}\right.$ instar larvae $)$ was seen in all oil types and their concentrations, as against $5 \%$ mortality in the control treatment (Fig. 4).

$\mathrm{LC}_{50}$ and related parameters of toxicity of oils for Aedes larvae and pupae are shown in Tables 2 and 3. Ginger showed the least value of $\mathrm{LC}_{50}(142 \mathrm{ppm})$ at $8 \mathrm{~h}$ to kill $1^{\text {st }}$ instar larvae with p-value $=0.00$ and at $16 \mathrm{~h}, \mathrm{LC}_{50}$ of $1^{\text {st }}$ instar larvae was $8.5 \mathrm{ppm}$ with $0.58 \mathrm{p}$-value (Table 2). In case of $2^{\text {nd }}$ instar larvae, the $\mathrm{LC}_{50}$ value of eucalyptus oil at 8 $\mathrm{h}$ with $0.47 \mathrm{p}$-values was very high $(571 \mathrm{ppm})$ followed by peppermint (463 ppm), ginger (181 ppm), neem (76.5 ppm) and basil (53 ppm) however, eucalyptus was found to be the best after 24 and $48 \mathrm{~h}$ with $99 \mathrm{ppm}$ and $86 \mathrm{ppm}$, respectively. In case of $3^{\text {rd }}$ instar larvae, after $8 \mathrm{~h}$ basil was the best with $\mathrm{LC}_{50}(198 \mathrm{ppm})$ followed by peppermint (226 $\mathrm{ppm})$, neem (372 ppm), ginger (395 ppm) and eucalyptus (591 ppm), however, neem was found to be the best after 24 $\mathrm{h}(117 \mathrm{ppm})$ and eucalyptus after $48 \mathrm{~h}$ with $\mathrm{LC}_{50}(145 \mathrm{ppm})$. Eucalyptus oil with least $\mathrm{LC}_{50}$ value (301 ppm) for 24 hours with $0.98 \mathrm{p}$-value was followed by ginger ( $464 \mathrm{ppm}$ ) at 24 and $48 \mathrm{~h}$, respectively for $4^{\text {th }}$ instar larvae. The $\mathrm{LC}_{50}$ value was less for $48 \mathrm{~h}$ with $0.833 \mathrm{p}$-value in case of pupae (Table $3)$.

\section{Discussion}

The oils of E. globules and M. piperita proved themselves as highly toxic to mosquito larvae $\left(1^{\text {st }}, 2^{\text {nd }}, 3^{\text {rd }}, 4^{\text {th }}\right.$ instar larvae

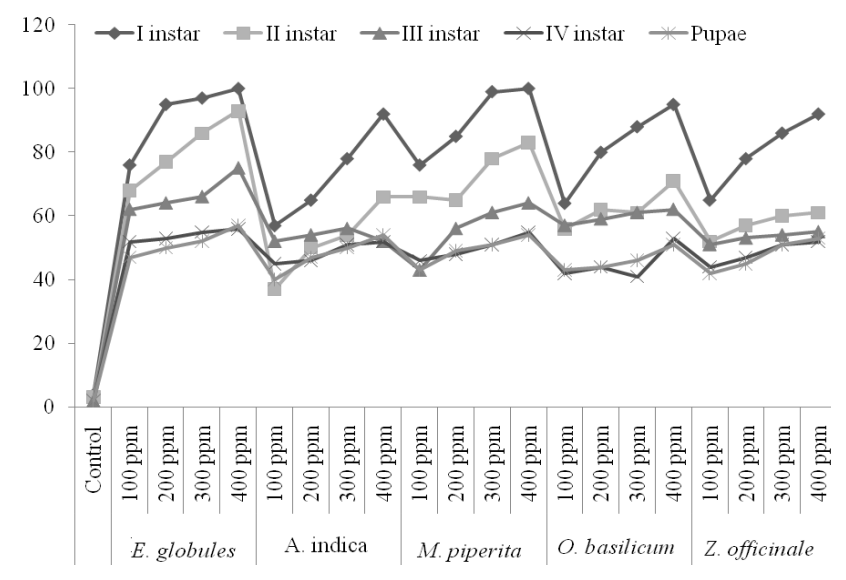

Fig. 3: Mortality (\%) of various life stages of Ae. aegypti mosquitoes after 24 hours in the concentrations of different plant oils

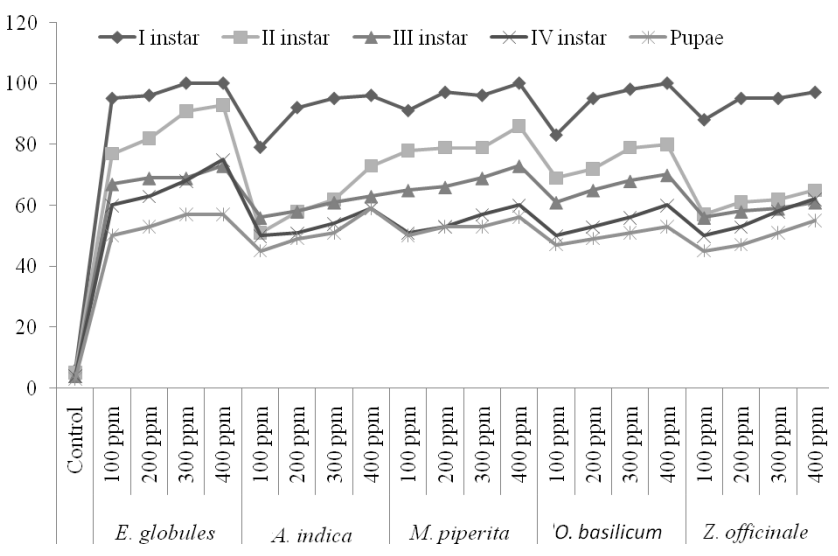

Fig. 4: Mortality (\%) of different life stages of Ae. aegypti mosquitoes after $48 \mathrm{~h}$ with different concentrations of different plant oils

and pupae) and this response was time and concentration dependent in all larval stages and pupae as well. These results are in agreement with earlier workers who have exhibited effectiveness and economy in using these oils where plant materials are abundantly available (Jang et al., 2002; Tripathi et al., 2002; Amer and Mehlhorn, 2006; Okumu et al., 2007; Aivazi and Vijayan, 2008; Kovendan et al., 2007; Silva et al., 2008; Abdel-Ghaffar et al., 2009). The active compounds from plant oils have been isolated and their repellent and contact activities are well reported. The limonoids from neem oil were found the effective alternative to conventional synthetic insecticides for the control of (100\%) Culex uinquefasciatus, (90\%) Ae. aegypti and (85\%) Ae. stephensi within $24 \mathrm{~h}$ (Ansari et al., 2000; SenthilNathan et al., 2006). We also found $90 \%$ mortality at 400 ppm after $24 \mathrm{~h}$ in case of $1^{\text {st }}$ instar Aedes larvae and more than $75 \%$ even at low concentrations (200 and 100 ppm). A total of $91 \%$ mortality was observed after $48 \mathrm{~h}$. The variation of solvent for extraction of plant oils and extract almost yielded high control rate of mosquitoes. The leaf and flower 
extracts in acetone, chloroform, ethyl acetate, hexane and methanol yielded high mortality against the $4^{\text {th }}$ instar larvae of mosquito and highest mortality was observed in chloroform and hexane extract of $O$. sanctum (Anees, 2008). Our study also revealed that the solvent used for extraction also had a strong effect on the mortality of different life stages of mosquitoes. We observed up to $6 \%$ mortality after $48 \mathrm{~h}$ in case of $1^{\text {st }}$ larvae in the control treatments and more than $3 \%$ in control treatments running along with $2^{\text {nd }}, 3^{\text {rd }}, 4^{\text {th }}$ instars and pupae after $48 \mathrm{~h}$. The essential rhizome oil from ginger was the most potent larvicide against the An. gambiae (Ajaiyeoba et al., 2008; Pushpanathan et al., 2008). These oils should be tested in the field with a knapsack sprayer to check their efficacy, because Prabhu et al. (2011) reported the efficacy of Moringa oleifera seed extracts against malarial vector (Anopheles stephensi) as more than $90 \%$ reduction in larvae after $72 \mathrm{~h}$. It is concluded from this study that essential oils from E. globules and M. piperita have strong larvicide potential and could be very effective against the larvae of Ae. aegypti.

\section{References}

Abbott, W.S., 1925. A method of computing the effectiveness of an insecticide. J. Econ. Entomol., 18: 265-267

Abdel-Ghaffar, F., M. Semmler, K. Al-Rasheid, S. Klimpel and H. Mehlhorn, 2009. Efficacy of a grapefruit extract on head lice: a clinical trial. Parasitol. Res., 106: 445-449

Aivazi, A. and V.A. Vijayan, 2008. Larvicidal activity of oak Quercusin fectoria Oliv. (Fagaceae) gall extracts against Anopheles stephensi Liston. Parasitol. Res., 104: 1289-1293

Ajaiyeoba, E.O., W. Sama, E.E. Essien, J.O. Olayemi, O. Ekundayo, T.M. Walker and W.N. Setzer, 2008. Larvicidal activity of turmerone rich essential oils of Curcuma longa leaf and rhizome from Nigeria on Anopheles gambiae. Pharm. Biol., 46: 279-282

Akram, W., H.A.A. Khan and F. Hafeez, 2010. Potential of citrus seed extracts against dengue fever mosquito, Aedes albopictus (Skuse) (Culicidae: Diptera). Pak. J. Bot., 42: 3343-3348

Amer, A. and H. Mehlhorn, 2006. Repellency effect of forty-one essential oils against Aedes, Anopheles and Culex mosquitoes. Parasitol. Res., 99: 478-490

Anees, A.M., 2008. Larvicidal activity of Ocimum sanctum Linn. Parasitol. Res., 103: 1451-1453

Anonymous, 2013. Evaluation Report on Project: Prevention and Control Program of Epidemics in Punjab. P\&D department, Civil Secretariat, Lahore-Punjab, Pakistan

Ansari, M.A., P. Vasudevan, M. Tandon and R.K. Razdan, 2000. Larvicidal and mosquito repellent action of peppermint (Mentha piperita) oil. Biores. Technol., 71: 267-271

Bakkali, F., S. Averbeck, D. Averbeck and M. Idaomar, 2008. Biological effects of essential oils - A Review. Food Chem. Toxicol., 46: 446-475

Bokhari, N.A., I. Siddiqui, K. Perveen, I. Siddique, M.S. Alwahibi, D.W.A. Soliman and M. Al-Subeie, 2014. Potential of different parts of neem (Azadirachta indica) extracts in controlling Rhizoctonia solani infestation. Int. J. Agric. Biol., 16: 639-643

Chantraine, J.M., D. Laurent, C. Ballivian, G. Saavedra, R. Ibanez and L.A. Vilaseca, 1998. Insecticidal activity of essential oils on Aedes aegypti larvae. Phytother. Res., 12: 350-354

Cheng, S.S., H.T. Chang, C.Y. Lin, P.S. Chen, C.G. Huang, W.J. Chen and S.T. Chang, 2009. Insecticidal activities of leaf and twig essential oils from Clausena excavata against Aedes aegypti and Aedes albopictus larvae. Pest Manag. Sci., 65: 339-343

Finney, D.J., 1971. Probit Analysis: A Statistical Treatment of the Sigmoid Response Curves, ${ }^{\text {rd }}$ edition. Cambridge University Press, London
Gbolade, A.A., A.D. Dyedele, M.B. Sosan, F.B. Adewayin and O.I. Soyela, 2000. Mosquito repellent activities of essential oils from two Nigerian Ocimum species. J. Trop. Med. Plants, 1: 146-148

Hafeez, F., W. Akram, A. Suhail and M.A. Khan, 2011. Adulticidal action of ten citrus oils against Aedes albopictus (Diptera: Culicidae). Pak. J. Agric. Sci., 47: 241-244

Jang, Y.S., M.K. Kim, Y.J. Ahn and H.S. Lee, 2002. Larvicidal activity of Brazilian plants against Aedes aegypti and Culex pipiens Pallens (Diptera: Culicidae). Agric. Chem. Biotech., 44: 23-26

Junwei, Z., Z. Xiaopeng, T.L. Yanma, L. Ting, Q. Kuen, H. Yuhua, X Suqin and T. Brad, 2006. Adult repellency and larvicidal activity of five plant essential oils against mosquitoes. J. Amer. Mosq. Cont. Assoc., 3: 515-522

Kovendan, K., K. Murugan and S. Vincent, 2007. Larvicidal activity of some Euphorbiaceae plant extracts against Aedes aegypti and Culex quinquefasciatus (Diptera: Culicidae). Parasitol. Res., 102: 867-873

Kumar, K., R. Warikoo and N. Wahab, 2011. Relative larvicidal efficacy of three species of peppercorns against dengue fever mosquito, Aedes aegypti L. J. Entomol. Res. Soc., 13: 27-36

Mohtar, M., M. Yarmo and A. Kardri, 1999. The effects of Nerium indicum leaf extract on Aedes aegypti larvae. J. Trop. Forest Prod., 5: 87-92

Naz, S., A. Maqbool, M.U.D. Ahmad and A.A. Anjum, 2014. Toxins of Bacillus thuringiensis var. israelensis for control of malaria vector Anopheles stephensi under laboratory and semi field conditions. Int. J. Agric. Biol., 16: 966-970

Okumu, F.O., B.G. Knols and U. Fillinger, 2007. Larvicidal effects of a neem (Azadirachta indica) oil formulation on the malaria vector Anopheles gambiae. Malar. J., 6: 63

Prabhu, K., K. Murugan, A. Nareshkumar, N. Ramasubramanian and S. Bragadeeswaran, 2011. Larvicidal and repellent potential of Moringa oleifera against malarial vector, Anopheles stephensi Liston (Insecta: Diptera: Culicidae). Asian Pac. J. Trop. Biomed., 1: 124-129

Pushpanathan, T., A. Jebanesan and M. Govindarajan, 2008. The essential oil of Zingiber officinalis Linn (Zingiberaceae) as a mosquito larvicidal and repellent agent against the filarial vector Culex quinquefasciatus Say (Diptera: Culicidae). Parasitol. Res., 102: 1289-1291

Sadr ud Din, W. Akram, H.A.A. Khan, A. Hussain and F. Hafeez, 2011 Citrus waste-derived essential oils: alternative larvicides for dengue fever mosquito, Aedes albopictus (Skuse) (Culicidae: Diptera). Pak. J. Zool., 43: 367-372

Sarwar, M., N. Ahmad and M. Toufiq, 2009. Host plant resistance relationships in chickpea (Cicer arietinum L.) against gram pod borer (Helicoverpa armigera Hubner). Pak. J. Bot., 41: 3047-3052

Senthil-Nathan, S., S. Kalaivani and K. Sehoon, 2006. Effects of Dysoxylum malabaricum Bedd. (Meliaceae) extract on the malarial vector Anopheles stephensi Liston (Diptera: Culicidae). Biores. Technol., 97: 2077-2083

Silva, W.J., G.A.A. Doria, R.T. Maia, R.S. Nunes, G.A. Carvalho, A.F. Blank, P.B. Alves, R.M. Marcal and S.C.H. Cavalcanti, 2008 Effects of essential oils on Aedes aegypti larvae: alternatives to environmentally safe insecticides. Biores. Technol., 99: 3251-3255

Sumroiphon, S., C. Yuwaree, C. Arunlertaree, N. Komalamisra and Y. Rongsriyam, 2006. Bioactivity of citrus seed for mosquito-borne diseases larval control. Southeast Asian J. Trop. Med. Public Health, 37(Suppl. 3): 123-127

Tiwary, M.S., N. Naik, D.K. Tewary, P.K. Mittal and S. Yadav, 2007. Chemical composition and larvicidal activities of the essential oil of Zanthoxylum armatum DC (Rutaceae) against three mosquito vectors. J. Vect. Borne Dis., 44: 198-204

Tripathi, A.K., V. Prajapati, N. Verma, J.R. Bahl, R.P. Bansal and S.P.S. Khanuja, 2002. Bioactivities of the leaf essential oil of Curcuma longa (var. Ch-66) on three species of stored- product beetles (Coleoptera). J. Econ. Entomol., 95: 183-189

WHO, 2009. Report of the WHO Informal Consultation on the Evaluation on the Testing of Insecticides, Vol. 1, p: 69. CTD/WHO PES/IC/96

Yang, Y.C., S.G. Lee, H.K. Lee, M.K. Kim, S.H. Lee and H.S. Lee, 2002. A piperidine amide extracted from Piper longum $\mathrm{L}$. fruit shows activity against Aedes aegypti mosquito larvae. J. Agric. Food Chem., 50: 3765-3767

Received 03 October 2014; Accepted 29 November 2014) 